\title{
Effect of supplementation of allicin on methanogenesis and ruminal microbial flora in Dorper crossbred ewes
}

Tao Ma ${ }^{1 \dagger}$, Dandan Chen ${ }^{1 \dagger}$, Yan Tu' ${ }^{1}$, Naifeng Zhang ${ }^{1}$, Bingwen $\mathrm{Si}^{1}$, Kaidong Deng ${ }^{2}$ and Qiyu Diao ${ }^{1 *}$

\begin{abstract}
Background: Garlic extracts have been reported to be effective in reducing methanogenesis. Related mechanisms are not well illustrated, however, and most studies have been conducted in vitro. This study investigates the effects of supplementary allicin (AL) in sheep diet on in vivo digestibility, rumen fermentation, and shifts of microbial flora.

Methods: Two experiments were conducted using Dorper $\times$ thin-tailed Han crossbred ewes. In experiment 1 , eighteen ewes ( $60.0 \pm 1.73 \mathrm{~kg} \mathrm{BW}$ ) were randomly assigned for 29 days to either of two dietary treatments: a basal diet or the basal diet supplemented with $2.0 \mathrm{~g} \mathrm{AL/head \cdot day} \mathrm{to} \mathrm{investigate} \mathrm{supplementary} \mathrm{AL} \mathrm{on} \mathrm{nutrient} \mathrm{digestibility} \mathrm{and}$ methane emissions. In experiment 2, six ewes (65.2 $\pm 2.0 \mathrm{~kg} \mathrm{BW})$ with ruminal canulas were assigned to the same two dietary treatments as in experiment 1 for 42 days to investigate supplementary AL on ruminal fermentation and microbial flora. The methane emissions were determined using an open-circuit respirometry system and microbial assessment was done by qPCR of 165 rRNA genes.
\end{abstract}

Results: Supplementary AL increased the apparent digestibility of organic matter $(P<0.001)$, nitrogen $(P=0.006)$, neutral detergent fiber $(P<0.001)$, and acid detergent fiber $(P=0.002)$. Fecal nitrogen output was reduced $(P=0.001)$ but urinary nitrogen output was unaffected $(P=0.691)$, while nitrogen retention $(P=0.077)$ and nitrogen retention/ nitrogen intake $(P=0.077)$ tended to increase. Supplementary AL decreased methane emissions scaled to metabolic bodyweight by $5.95 \%(P=0.007)$ and to digestible organic matter intake by $8.36 \%(P=0.009)$. Ruminal pH was unaffected $(P=0.601)$ while ammonia decreased $(P=0.024)$ and total volatile fatty acids increased $(P=0.024)$ in response to supplementary AL. Supplementary AL decreased the population of methanogens $(P=0.001)$ and tended to decrease that of protozoans $(P=0.097)$, but increased the populations of $F$. succinogenes $(P<0.001)$, $R$. flavefaciens $(P=0.001)$, and $B$. fibrisolvens $(P=0.001)$.

Conclusions: Supplementation of AL at $2.0 \mathrm{~g} /$ head day effectively enhanced OM, N, NDF, and ADF digestibility and reduced daily methane emissions $\left(L / \mathrm{kg} \mathrm{BW}^{0.75}\right)$ in ewes, probably by decreasing the population of ruminal protozoans and methanogens.

Keywords: Allicin, Digestibility, Ewe, Methane, Microbial flora

\footnotetext{
* Correspondence: diaoqiyu@caas.cn

Tao Ma and Dandan Chen are considered co-first authors

${ }^{\dagger}$ Equal contributors

${ }^{1}$ Feed Research Institute, Chinese Academy of Agricultural Sciences, Key

Laboratory of Feed Biotechnology of the Ministry of Agriculture, Beijing

100081, China

Full list of author information is available at the end of the article
} 


\section{Background}

Methane has been proven the second-most anthropogenic greenhouse gas [1] because of its concentration in the atmosphere and its global warming potential is 21 times that of carbon dioxide [2]. Domestic ruminants have been blamed for substantially contributing to methane emissions. It would be of great value to decrease methane emissions, as methane production in ruminants represents a loss of about $2-15 \%$ of feed energy [3]. In addition, limiting methane emissions from ruminants is not only beneficial for environmental protection, but also has potential economic benefits that could be derived from the application of carbon trading markets [4].

Numerous chemical additives to ruminant feed have been used to inhibit methane emissions. These chemicals, however, are either toxic to hosts or exhibit only transient effects on methanogenesis [5] and so-called 'natural products' seem to be more acceptable to consumers. Plants that contain bioactive products, such as essential oils, saponins, and tannins, can protect themselves against microbial and insect attack [6].

Allicin (AL) is one of the active components of garlic (Allium sativum); it has a variety of antimicrobial activities [7]. Studies of the effect of AL on methane emissions are still limited and previous studies focused mainly on the effect of other garlic components, such as garlic oil [8], garlic powder [9], and diallyl disulfide (DADS) [10], on nutrient digestibility and methane emissions by sheep and cows. Although it is generally accepted that those supplements' activities relate to altering microbial fermentation or flora in the rumen, related mechanisms could be different. Microscopy used to be a key method in microbial quantification, and although this method allows one to determine the total number of microorganisms accurately, it has almost no capacity to distinguish among different species of bacteria [11]. Real-time quantitative PCR (q-PCR) methods can help overcome this problem and allow one to quantify specific bacteria or groups of microorganisms accurately. This study therefore investigated the effect of $\mathrm{AL}$ on ruminal fermentation, digestibility, and populations of protozoans, methanogens, and four cellulolytic bacteria in the rumen by using a q-PCR technique based on the 16S rRNA gene. We hypothesized that supplementary AL could reduce the population of protozoans and methanogens, but might have different effects on cellulolytic bacteria.

\section{Methods}

This study was conducted from March 2013 to May 2013 at the Experimental Station of the Chinese Academy of Agricultural Sciences (CAAS), Beijing, China. The experimental procedures were approved by the Animal Ethics Committee of CAAS, and humane animal care and handling procedures were followed throughout the experiment.

\section{Animals, treatments, and experimental procedure Experiment 1}

Eighteen primiparous Dorper $\times$ Thin-tailed Han crossbred ewes $(60.0 \pm 1.73 \mathrm{~kg} \mathrm{BW}), 12$ months of age, were randomly assigned to either of two dietary treatments: a basal diet or the basal diet supplemented with allicin (AL) at $2.0 \mathrm{~g} / \mathrm{head} \cdot$ day (extracted from underground bulbs of garlic, Xi'an Feida Bio-Tech Co., Ltd., Shanxi, China). The basal diets included pelleted total mixed rations (TMR) and Chinese wild rye hay (Table 1); in the experimental diet, allicin was mixed with pelleted TMR. The ewes were fed $1500 \mathrm{~g}$ pelleted TMR at $0800 \mathrm{~h}$ and $200 \mathrm{~g}$ of Chinese wild rye hay at $1200 \mathrm{~h}$ daily. This feeding level was formulated to meet the maintenance and growth requirements of yearling ewes (60 kg BW) according to NRC (2007) [12]. All animals were housed in individual pens and had free access to fresh water over the experimental period.

All ewes were moved into metabolism crates after a 14-day adaptation to diets and after another 7-day adaptation to metabolism crates; the amount of feed offered, refused, and feces were weighed daily and homogenized. A $10 \%$ sample was collected during an 8-day collection period as described by $\mathrm{Ma}$ et al. [13]. Urine was collected daily in buckets containing $100 \mathrm{~mL}$ of $10 \%$ (v/v)

Table 1 Ingredients and chemical compositions of experimental diets (\% of DM)

\begin{tabular}{lll}
\hline Item $^{\text {b }}$ & Total mixed ration & Chinese wildrye hay \\
\hline Ingredient, \% of DM & & \\
Corn & 17.0 & \\
Soybean meal & 12.0 & \\
Chinese wildrye hay & 68.7 & \\
CaHPO $_{4}$ & 1.35 & \\
Limestone $_{\text {NaCl }}$ & 0.25 & \\
Premix & \\
Chemical composition (deteremined) & 0.50 & \\
DM (\% as fed) & 88.6 & 91.4 \\
OM, & 80.8 & 90.6 \\
GE, MJ/kg of DM & 17.2 & 17.6 \\
CP & 12.2 & 8.50 \\
NDF & 41.4 & 70.7 \\
ADF & 21.8 & 38.1 \\
\hline
\end{tabular}

${ }^{\mathrm{a}}$ Manufactured by Precision Animal Nutrition Research Centre, Beijing, China. The premix contained (per kg): $22.1 \mathrm{~g} \mathrm{Fe}, 2.25 \mathrm{~g} \mathrm{Cu}, 9.82 \mathrm{~g} \mathrm{Mn}, 27.0 \mathrm{~g} \mathrm{Zn}$, $0.19 \mathrm{~g} \mathrm{Se}, 0.54 \mathrm{~g} \mathrm{l}, 0.09 \mathrm{~g} \mathrm{Co}, 3.2 \mathrm{~g}$ Vitamin A, $0.8 \mathrm{~g}$ Vitamin $D_{3}$, and $0.4 \mathrm{~g}$ Vitamin E

${ }^{b} \mathrm{DM}$ dry matter, OM organic matter, GE gross energy, $\mathrm{CP}$ crude protein, NDF neutral detergent fiber, ADF acid detergent fiber 
$\mathrm{H}_{2} \mathrm{SO}_{4}$. The volume was measured and a sample $(10 \mathrm{~mL} / \mathrm{L}$ of total volume) was collected and stored at $-20{ }^{\circ} \mathrm{C}$ until analysis. Samples of feed, ort, feces, and urine were pooled to form a composite sample for each ewe.

Ruminal methane production was measured using an open-circuit respirometry system (Sable Systems International, Las Vegas, NV, USA) with three metabolism cages, each fitted with a polycarbonate head box. Measurements of methane production were staggered because only three measurement units were available. On days $0,2,4$, and 6 of each 8-day collection period, the ewes were moved in sequence from their metabolism cages to metabolism cages equipped with head boxes for digestibility assays and methane output assessments. After a 24 hour adaptation period, individual methane production was measured over a 24 hour period as described by Deng et al. [14]. All ewes had been previously trained for confinement in head boxes attached to metabolism cages.

\section{Experiment 2}

Six ruminally cannulated Dorper $\times$ Thin-tailed Han crossbred ewes $(65.2 \pm 2.0 \mathrm{~kg} \mathrm{BW})$ were divided into two groups of three each according to crossover design and fed either of the following diets: basal diet or basal diet supplemented with allicin (AL, $2.0 \mathrm{~g} / \mathrm{head}$-day). Composition of the basal diets and the experimental regime were the same as in Experiment 1. The experiment lasted for 42 days, which consisted of two periods lasting 21 days, including 7 days of adaptation. On days 16 and 37 , two $50 \mathrm{~mL}$ samples of ruminal digesta were collected from rumen cannula using a syringe attached to a plastic tube (20-mm internal diameter), at $0,1,3,6$, and $9 \mathrm{~h}$ after the morning feeding for the measurements of ruminal fermentation parameters and microbial flora populations. The $\mathrm{pH}$ was measured immediately using a $\mathrm{pH}$ meter (Model PB-10, Sartorius Co., Goettingen, Germany) and all samples were frozen in liquid nitrogen within $5 \mathrm{~min}$ and then stored at $-80{ }^{\circ} \mathrm{C}$ until needed.

\section{Analytical procedures}

Dry matter (DM) content was measured by drying samples in an air-forced oven at $135{ }^{\circ} \mathrm{C}$ for $2 \mathrm{~h}$ (method 930.15; AOAC, 1990) [15]. Ash content was measured by placing samples into a muffle furnace at $550{ }^{\circ} \mathrm{C}$ for $5 \mathrm{~h}$ (method 938.08; AOAC, 1990) [15]. Organic matter $(\mathrm{OM})$ was measured as the difference between DM and the ash content. Nitrogen $(\mathrm{N})$ was measured according to the methods of Kjeldahl, using Se as a catalyst. Crude protein $(\mathrm{CP})$ was calculated as $6.25 \times \mathrm{N}$. Gross energy (GE) was measured using a bomb calorimeter (C200, IKA Works Inc., Staufen, Germany). Ether extracts (EE) were measured by weight loss of the DM on extraction with diethyl ether in Soxhlet extraction apparatus for $8 \mathrm{~h}$ (method 920.85; AOAC, 1990) [15]. Neutral-detergent fiber (NDF) and acid-detergent fiber (ADF) were measured according to Van Soest et al. [16] and Goering and Van Soest [17], respectively. NDF was measured without a heat stable amylase and expressed inclusive of residual ash. Ruminal VFA was measured according to the procedure described by $\mathrm{Ma}$ et al. [18] and ammonia $\mathrm{N}$ was assessed according to Broderick and Kang [19].

Total DNA from rumen fluid was extracted according to a bead-beating method as described by Zhang et al. [20]. The microbial cells were resuspended in a lysis buffer in tubes containing zirconium beads, which were then bead-beaten at $4600 \mathrm{rpm}$ for $3 \mathrm{~min}$ in a mini-bead beater (MM400, Retsch, Hann, Germany) followed by phenol-chloroform extraction [21]. After centrifugation of the sample at $14,000 \times \mathrm{g}$ for $15 \mathrm{~min}$ at $4{ }^{\circ} \mathrm{C}$, the supernatant was mixed with a glass milk kit (Gene Clean II kit, ZZBio Co., Ltd, Shanghai, China) and washed before a final elution step to release the DNA from the glass milk.

The amplifying primer of microbial flora, including total bacteria, methanogens, protozoans, F. succinogenes, $R$. albus, $R$. flavefaciens, and B. fibrisolvens are listed in Table 2 as described by Denman and McSweeney [22]. All primers were verified by sequencing and meltingcurve analysis using a $\mathrm{C} 1000^{\text {ma }}$ thermal cycler and bundled software CFX96 Manager $^{\text {Tx }}$ software version 2.1 (Bio-Rad laboratories, Inc., Hercules, CA, USA). The PCR products were purified by gel extraction and ligated into the pGM-T vector (Promega) and the recombinant plasmids were extracted using a plasmid minikit (Omega) according to the manufacturer's instructions and quantified by $\mathrm{A}_{260}$ measurements. Standard curves for microbes were generated with $10^{1}-10^{7}$ copies of recombinant plasmids per $\mu \mathrm{L}$. The qPCR was performed

Table 2 Primers for qPCR assay

\begin{tabular}{|c|c|c|}
\hline Target species & Primer sequence $\left(5^{\prime} \rightarrow 3^{\prime}\right)^{\mathrm{a}}$ & Amplicon \\
\hline \multirow[t]{2}{*}{ Total bacteria } & F: CGGTGAATACGTTCYCGG & \multirow[t]{2}{*}{123} \\
\hline & R: GGWTACCTTGTTACGACTT & \\
\hline \multirow[t]{2}{*}{ Methanogens } & F: TTCGGTGGATCDCARAGRGC & \multirow[t]{2}{*}{140} \\
\hline & R: GBARGTCGWAWCCGTAGAATCC & \\
\hline \multirow[t]{2}{*}{ Protozoans } & F: GCTITCGWTGGTAGTGTATT & \multirow[t]{2}{*}{223} \\
\hline & R: CTTGCCCTCYAATCGTWCT & \\
\hline \multirow[t]{2}{*}{ F. succinogenes } & F: GTTCGGAATTACTGGGCGTAAA & \multirow[t]{2}{*}{121} \\
\hline & R: CGCCTGCCCCTGAACTATC & \\
\hline \multirow[t]{2}{*}{ R. flavefaciens } & F: GATGCCGCGTGGAGGAAGAAG & \multirow[t]{2}{*}{286} \\
\hline & R: CATTTCACCGCTACACCAGGAA & \\
\hline \multirow[t]{2}{*}{ R. albus } & F: GTTTTAGGATTGTAAACCTCTGTCTT & \multirow[t]{2}{*}{270} \\
\hline & R: CCTAATATCTACGCATTTCACCGC & \\
\hline \multirow[t]{2}{*}{ B. fibrisolvens } & F: TAACATGAGAGTITGATCCTGGCTC & \multirow[t]{2}{*}{135} \\
\hline & R: CGTTACTCACCCGTCCGC & \\
\hline
\end{tabular}

aprimers were designed according to Denman and McSweeney [22] 
using SsoFast EvaGreen Supermix (Bio-Rad), a C1000 thermal cycler qPCR detection system, and genomic DNA as the template. All PCR amplifications used the following thermal cycling: $95{ }^{\circ} \mathrm{C}$ for $10 \mathrm{~min}$, followed by 40 cycles of $94{ }^{\circ} \mathrm{C}$ for $20 \mathrm{~s}, 60{ }^{\circ} \mathrm{C}$ for annealing, extension, and collection of fluorescent signals. All samples were prepared from the ewes and each sample was assayed in triplicate.

\section{Statistical analyses}

The data on digestibility and nitrogen balance were analyzed by the independent sample $t$-test. Data referring to ruminal fermentation parameters and microbial flora measured at each sampling time were analyzed using repeated measures data of ANOVA. All statistical analyses were performed by using SPSS (SPSS Inc., Chicago, IL, USA) and significant differences were accepted if $P<0.05$.

\section{Results}

Supplementation of AL increased apparent digestibility of OM $(P<0.001), \mathrm{N}(P=0.006)$, NDF $(P<0.001)$, and ADF $(P=0.002)$ (Table 3$)$. Daily fecal $\mathrm{N}$ output decreased from 10.7 to $9.34 \mathrm{~g} / \mathrm{d}(P<0.001)$ while urinary $\mathrm{N}$ output was unaffected $(P=0.691)$. Although no significant effect was observed, either $\mathrm{N}$ retention or the ratio of $\mathrm{N}$ retention/ $\mathrm{N}$ intake tended to increase $(P=0.071)$ when AL was added.

Supplementation of AL had no significant effect on daily methane output by ewes $(P>0.05)$, but decreased daily methane output from 2.85 to $2.69 \mathrm{~L} / \mathrm{kg} \mathrm{BW}^{0.75}(P=0.007)$ (Table 4). In addition, daily methane output decreased from 66.1 to $61.0 \mathrm{l}(P=0.009)$ when scaled to DOM intake by supplementary AL. Ruminal $\mathrm{pH}$ was similar for both

Table 3 Effects of supplementary allicin (AL) on the apparent digestibility of nutrients and nitrogen balance in ewes

\begin{tabular}{lllll}
\hline Item $^{\text {a }}$ & \multicolumn{2}{l}{ Treatments $^{\text {b }}$} & SEM & $P$ value \\
\cline { 2 - 3 } & Basal diet & AL & & \\
\hline DM intake, g/d & $1,512.4$ & $1,512.4$ & 0.029 & 0.524 \\
Apparent digestibility, \% & & & & \\
OM & 60.3 & 67.9 & 1.07 & $<0.001$ \\
N & 66.6 & 70.9 & 0.86 & 0.001 \\
NDF & 37.9 & 51.8 & 1.90 & $<0.001$ \\
ADF & 38.8 & 50.5 & 2.14 & 0.001 \\
Fecal N, g/d & 10.7 & 9.34 & 0.39 & 0.001 \\
Urinary N, g/d & 14.9 & 14.5 & 0.87 & 0.691 \\
N retention, g/d & 6.54 & 8.30 & 0.95 & 0.071 \\
N retention/N intake, \% & 20.3 & 25.8 & 2.10 & 0.071 \\
\hline
\end{tabular}

${ }^{\mathrm{a}} \mathrm{DM}$ dry matter, OM organic matter, $\mathrm{N}$ nitrogen, NDF neutral detergent fiber, ADF acid detergent fiber

${ }^{\mathrm{b}} \mathrm{CON}$ ewes fed basal diet, AL ewes fed basal diet supplemented with allicin
Table 4 Effects of supplementary allicin (AL) on daily methane production and ruminal fermentation in ewes

\begin{tabular}{|c|c|c|c|c|}
\hline \multirow[t]{2}{*}{ Item $^{a}$} & \multicolumn{2}{|c|}{ Treatments $^{\mathrm{b}}$} & \multirow[t]{2}{*}{ SEM } & \multirow[t]{2}{*}{$P$ value } \\
\hline & Basal diet & $\mathrm{AL}$ & & \\
\hline \multicolumn{5}{|l|}{ Methane production } \\
\hline L & 61.6 & 64.0 & 3.46 & 0.151 \\
\hline L/kg BW $W^{0.75}$ & 2.85 & 2.69 & 0.06 & 0.007 \\
\hline L/kg DOM intake & 66.1 & 61.0 & 2.02 & 0.009 \\
\hline $\mathrm{pH}$ & 5.98 & 5.96 & 0.04 & 0.601 \\
\hline Ammonia, mg/100 mL & 10.9 & 9.37 & 0.30 & 0.024 \\
\hline Total VFA, mmol/L & 109.4 & 125.1 & 4.15 & 0.014 \\
\hline \multicolumn{5}{|l|}{ Molar proportions, \% } \\
\hline Acetate & 72.2 & 69.7 & 0.59 & 0.023 \\
\hline Propionate & 14.8 & 14.9 & 0.42 & 0.906 \\
\hline Isobutyrate & 1.32 & 1.86 & 0.09 & 0.011 \\
\hline Butyrate & 9.43 & 11.0 & 0.24 & 0.003 \\
\hline Isovalerate & 1.37 & 1.68 & 0.08 & 0.054 \\
\hline Valerate & 0.89 & 0.71 & 0.04 & 0.363 \\
\hline Acetate:propionate & 4.98 & 4.83 & 0.16 & 0.455 \\
\hline
\end{tabular}

${ }^{\mathrm{a} B W}$ bodyweight, DOM digestible organic matter, VFA volatile fatty acids ${ }^{\mathrm{b}} \mathrm{CON}$ ewes fed basal diet, AL ewes fed basal diet supplemented with allicin

treatments $(P=0.601)$. Ammonia decreased from 10.9 to $9.37 \mathrm{mg} / \mathrm{dL}(P=0.024)$ while total VFA increased from 109.4 to $125.1 \mathrm{mmol} / \mathrm{L}(P=0.014)$ by supplementation of AL. The molar proportion of acetate decreased from 72.2 to $69.7 \%(P=0.023)$, while that of isobutyrate and butyrate increased from 1.32 to $1.86 \%(P=0.011)$ and from 9.43 to $11.0 \%(P=0.003)$, respectively, by supplementation of AL. No difference was observed in molar proportions of propionate $(P=0.155)$, valerate $(P=0.363)$, and the ratio of acetate to propionate $(P=0.455)$. Supplementary AL tended to increase the molar proportion of isovalerate $(P=0.054)$.

Supplementary AL increased the total bacteria $(P<0.001)$, (Table 5), decreased the population of methanogens $(P=0.001)$, and tended to decrease the population of protozoans $(P=0.097)$. Populations of $F$. succinogenes $(P<0.001), R$. flavefaciens $(P=0.001)$, and $B$. fibrisolvens $(P=0.001)$ were significantly increased by supplementation of AL, while no effect of AL was found on the population of $R$. albus $(P=0.675)$.

\section{Discussion}

The current study found that supplementation of AL increased the apparent digestibility of OM, N, NDF, and ADF. It is reported that AL is very unstable and quickly changes into a series of other sulfur-containing compounds such as DADS [23]. In a related study, it was reported that supplementation of DADS at $2 \mathrm{~g} / \mathrm{kg}$ of diet improved the apparent digestibility of OM and NDF in sheep [10]. Kamruzzaman et al. [24] also reported that 
Table 5 Effects of supplementary allicin (AL) on ruminal microbial population

\begin{tabular}{|c|c|c|c|c|}
\hline \multirow{2}{*}{$\begin{array}{l}\text { Microbial population, } \\
\text { per mL of ruminal fluid }\end{array}$} & \multicolumn{2}{|c|}{ Treatments $^{a}$} & \multirow{2}{*}{ SEM } & \multirow{2}{*}{$P$ value } \\
\hline & $\mathrm{CON}$ & $\mathrm{AL}$ & & \\
\hline Total bacteria, $\times 10^{10}$ & 7.36 & 12.10 & 0.72 & $<0.001$ \\
\hline Protozoans, $\times 10^{7}$ & 7.83 & 6.64 & 0.36 & 0.097 \\
\hline Methanogens, $\times 10^{7}$ & 9.23 & 4.53 & 0.79 & 0.001 \\
\hline F. succinogenes, $\times 10^{5}$ & 4.08 & 9.05 & 0.66 & $<0.001$ \\
\hline R. flavefaciens, $\times 10^{8}$ & 4.18 & 6.84 & 0.43 & 0.001 \\
\hline R. albus, $\times 10^{7}$ & 6.44 & 6.79 & 0.40 & 0.675 \\
\hline B. fibrisolvens, $\times 10^{9}$ & 9.71 & 15.20 & 0.89 & 0.001 \\
\hline
\end{tabular}

${ }^{\mathrm{a}} \mathrm{CON}$ ewes fed basal diet, AL ewes fed basal diet supplemented with allicin

replacing $10 \%$ of hay by garlic leaf, which retains the same bioactive components as the garlic bulb, could increase $\mathrm{N}$ digestibility in sheep. The increase in nutrient digestibility could be explained by the increase in the populations of cellulolytic bacteria (F. succinogenes, $R$. flavefaciens, and B. fibrisolvens) in the rumen as observed in current study, which in turn improved the utilization of dietary fiber and provided more carbohydrates to microbes.

Nitrogen retention is considered an index of protein status in ruminants. The lower $\mathrm{N}$ output in feces in the AL group is consistent with the higher digestibility of dietary $\mathrm{N}$, suggesting an improved utilization of dietary $\mathrm{N}$. Urinary $\mathrm{N}$ output was similar between the two groups in current study. When scaled to metabolic bodyweight, however, a significant decrease in the AL group was observed $\left(0.61\right.$ vs $\left.0.69 \mathrm{~g} / \mathrm{kg} \mathrm{BW}^{0.75} / \mathrm{d}, P<0.05\right)$. A reduction of urinary $\mathrm{N}$ excretion is desirable, as urinary $\mathrm{N}$ causes more waste and pollution to the environment than fecal $\mathrm{N}$, as feces could be utilized for crop production when used as a manure [25]. Supplementary AL tended to increase both $\mathrm{N}$ retention and the ratio of $\mathrm{N}$ retention/ $\mathrm{N}$ intake. The insignificant $\mathrm{N}$ retention could be due to the dosage of AL used in the current study. As reported by Wanapat et al. [9], supplementation of garlic powder at $40 \mathrm{~g} /$ day did not affect $\mathrm{N}$ retention, but at $120 \mathrm{~g} /$ day did improve $\mathrm{N}$ retention in steers.

The current study found that supplementation of $\mathrm{AL}$ decreased daily methane emissions $\left(\mathrm{L} / \mathrm{kg} \mathrm{BW}^{0.75}\right)$ or methane output scaled to DOM intake. Previous studies showed that methane production was suppressed in vitro by garlic oil $[26,27]$. Similar to our results, Klevenhusen et al. [10] found a decrease in methane output scaled to digested NDF intake when DADS was supplemented and Patra et al. [28] found that supplementary Allium sativum tended to reduce methane output scaled to digested DM intake by sheep. Zhu et al. [29] found that the final step of biohydrogenation was interrupted in the rumen of goats by infusion garlic oil; this may be related to its antibacterial activity. All these in vitro and in vivo results suggest that garlic components are effective in reducing methane emissions. This effect may be due to the reduction of methanogen or protozoan populations, as observed in current study. It has also been reported that endo- and ecto-symbiotic methanogens of protozoans could contribute up to $25 \%$ of rumen fluid methane emissions in sheep [30].

Supplementary AL decreased the ruminal concentration of ammonia, but increased that of total VFA, which is similar to results reported by Cardozo et al. [31] and Klevenhusen et al. [10], who supplemented various garlic components in vitro and in sheep diets, respectively. Again, those results could reflect enhanced utilization of dietary fibrous components by ruminal microbes as the population of $R$. flavefaciens increased. The change in the molar proportion of acetate, isobutyrate, and butyrate suggested that supplementary AL might affect rumen fermentation patterns by changing microbial populations. Reports of the effect of garlic components on ruminal VFA were inconsistent. Concentration of VFA and the molar proportion of acetate decreased, but the molar proportion of propionate and butyrate increased [26]; concentration of VFA and the molar proportion of propionate increased [9]; and neither the total concentration nor the molar proportion of VFA was affected by the additives [10]. The experimental differences among these results could be related to the experimental diets and dosage of the plant extract used.

Although not significant, the population of protozoans tended to decrease in response to supplementary AL. The effect of garlic by-products on protozoan numbers differed in different studies. Reuter et al. [32] reported that garlic extracts are effective against a host of protozoans. Kongmun et al. [33] investigated the effect of garlic powder on in vitro fermentation and found a reduced protozoan count. Anassori et al. [34] found that supplementing a basal diet with raw garlic or garlic oil effectively reduced number of total protozoans in sheep. Those discrepancies could be attributed to factors such as specific diet and supplementary dosage.

In the current study, supplementary AL decreased the population of methanogens by about $104 \%$. Most studies of the effect of garlic components on the population of methanogens were conducted in vitro. Chaves et al. [27] reported that supplementing garlic oil decreased methanogenic activities of mixed ruminal bacteria. More recently, Patra and $\mathrm{Yu}$ [35] reported that garlic oil could reduce the abundance of archaea. Observations of the reduction of methanogens in the current study coincide with those of in vitro results. The reduction of methanogens could be directly due to the inhibitive effect of garlic components. In addition, the decreased population of 
protozoans could also be responsible for the reduction in methanogens, as the total methanogen population declined in absolute number as well as in proportion to the total bacterial population in the absence of protozoans [36].

In our study, we quantified four main cellulolytic bacteria using a q-PCR system and observed significant increases in the populations of $F$. succinogenes, $R$. flavefaciens, and $B$. fibrisolvens in ewes supplemented with AL. Wanapat et al. [9] reported that supplementation of garlic powder did not affect the population of amylolytic or cellulolytic bacteria. Patra and $\mathrm{Yu}$ [35], however, reported that garlic oil effectively reduced the in vitro abundance of $F$. succinogenes, $R$. flavefaciens, and $R$. albus without affecting that of total bacteria. It should be noted that although garlic has been proven effective against some gram-negative or gram-positive bacteria, it is not a broadspectrum microbial inhibitor [37]. In addition, rumen is such a complicated system that in vitro studies could not completely reflect the situation in rumen. The increase in the population of those three cellulolytic bacteria could be more probably explained by the reduced populations of the protozoans that engulf bacteria. To our knowledge, there has been no study on the effect of garlic-related compounds on ruminal microbial flora in sheep; further study is needed to prove the effectiveness of AL in manipulating certain microbes.

\section{Conclusions}

Dietary supplementation of $\mathrm{AL}$ at $2.0 \mathrm{~g} / \mathrm{head} \cdot$ day effectively enhanced OM, N, NDF, and ADF digestibility and reduced daily methane emissions $\left(\mathrm{L} / \mathrm{kg} \mathrm{BW}^{0.75}\right)$ in ewes, probably by decreasing the population of ruminal protozoans and methanogens.

\section{Competing interests}

The authors declare that they have no competing interest.

\section{Authors' contributions}

DC carried out the whole animal experiment, including sample collection and determination. TM participated in the statistical analysis and wrote the draft. KD helped to revise the manuscript. YT, NZ, and BS participated in the design and coordination of the study. QD conceived of the study. All authors read and approved the final manuscript.

\section{Acknowledgements}

This study was funded by the Ministry of Science and Technology of the People's Republic of China (Program 2012BAD39B05) and earmarked fund for China Agriculture Research System (CARS-39). We thank C. Liu, C. Lou, S.-Q. Wang, X. Cui, X.-L. Chen, Y.-X. Xie, and Y. Xiao for their technical assistance. All authors participated in the writing of the manuscript and agreed with the final format.

\section{Author details}

${ }^{1}$ Feed Research Institute, Chinese Academy of Agricultural Sciences, Key Laboratory of Feed Biotechnology of the Ministry of Agriculture, Beijing 100081, China. ${ }^{2}$ College of Animal Science, Jinling Institute of Technology, Nanjing, Jiangsu 210038, China.
Received: 24 August 2015 Accepted: 9 December 2015

Published online: 15 January 2016

\section{References}

1. Goel G, Makkar HPS, Becker K. Effect of Sesbania sesban and Carduus pycnocephalus leaves and fenugreek (Trigonella foenum-graecum L.) seeds and their extracts on partitioning of nutrient from roughage and concentrate based feeds to methane. Anim Feed Sci Technol. 2008;147:72-89.

2. United Nations Framework Convention on Climate Change. Greenhouse Gas inventory data. Bonn: UNFCCC; 1996. https://unfecc.int/ghg_data/ online help/definitions/items/3817.php.

3. Hess HD, Beuret RA, Lotscher M, Hindrichsen IK, Machmüller A, Carulla JE, et al. Ruminal fermentation, methanogenesis and nitrogen utilization of sheep receiving tropical grass hay-concentrate diets offered with Sapindus saponaria fruits and Cratylia argentea foliage. Anim Sci. 2004;79:177-89.

4. Alford AR, Hegarty RS, Parnell PF, Cacho OJ, Herd RM, Griffith GR. The impact of breeding to reduce residual feed intake on enteric methane emissions from the Australian beef industry. Aust J Exp Agr. 2006;46:813-20.

5. Moss AR, Jouany JP, Newbold CJ. Methane production by ruminants: its contribution to global warming. Ann Zootechnol. 2000;49:231-5.

6. Wallace RJ, McEwan NR, McIntosh FM, Teferedegne B, Newbold CJ. Natural products as manipulators of rumen fermentation. Asian-Austral J Anim Sci. 2002;15:1458-68.

7. Ankri S, Mirelman D. Antimicrobial properties of allicin from garlic. Microbes Infect. 1999;1:125-9.

8. Yang WZ, Benchaar C, Ametaj BN, Chaves AV, He ML, McAllister TA. Effects of garlic and juniper berry essential oils on ruminal fermentation and on the site and extent of digestion in lactating cows. J Dairy Sci. 2007;90:5671-81.

9. Wanapat M, Khejornsart P, Pakdee P, Wanapat S. Effect of supplementation of garlic powder on rumen ecology and digestibility of nutrients in ruminants. J Sci Food Agri. 2008;88:2231-7.

10. Klevenhusen F, Zeitz JO, Duval S, Kreuzer M, Soliva CR. Garlic oil and its principal component diallyl disulfide fail to mitigate methane, but improve digestibility in sheep. Anim Feed Sci Technol. 2011;166:356-63.

11. Rinsoz T, Duquenne P, Greff-Mirguet G, Oppliger A. Application of real-time PCR for total airborne bacterial assessment: Comparison with epifluorescence microscopy and culture-dependent methods. Atmos Environ. 2008:42:6767-74.

12. NRC. Nutrient requirements of small ruminants. Sheep, goats, cervids and New world camelids. Washington, DC: National Academy Press; 2007.

13. Ma T, Chen DD, Tu Y, Zhang NF, Si BW, Deng KD, et al. Effect of dietary supplementation with resveratrol on nutrient digestibility, methanogenesis and ruminal microbial flora in sheep. J Anim Physiol An N. 2015;99(4):676-83.

14. Deng KD, Jiang CG, Tu Y, Zhang NF, Liu J, Ma T, et al. Energy requirements of Dorper crossbred ewe lambs. J Anim Sci. 2014;92:2161-9.

15. AOAC. Official methods of analysis. 15th ed. Washington, DC: Association of Official Analytical Chemists; 1990.

16. Van Soest PJ, Robertson JB, Lewis BA. Methods for dietary fiber, neutral detergent fiber and non-starch polysaccharides in relation to animal nutrition. J Dairy Sci. 1991;74:3583-97.

17. Goering HG, Van Soest JP. Forage fiber analysis. Agricultural handbook, vol. 379. USA: UPSDA; 1970.

18. Ma T, Deng KD, Tu Y, Zhang NF, Jiang CG, Liu J, et al. Effect of dietary forage-to-concentrate ratios on urinary excretion of purine derivatives and microbial nitrogen yields in the rumen of Dorper crossbred sheep. Livest Sci. 2014;160:37-44.

19. Broderick GA, Kang JH. Automated simultaneous determination of ammonia and total amino acids in ruminal fluid and in vitro media. J Dairy Sci. 1980;63:64-75.

20. Zhang CM, Guo YQ, Yuan ZP, Wu YM, Wang JK, Liu JX, et al. Effect of octadeca carbon fatty acids on microbial fermentation, methanogenesis and microbial flora in vitro. Anim Feed Sci Technol. 2008;146:259-69.

21. Zoetendal EG, Akkermans AD, De Vos WM. Temperature gradient gel electrophoresis analysis of 165 rRNA from human fecal samples reveals stable and host-specific communities of active bacteria. Appl Environ Microb. 1998;64:3854-9.

22. Denman SE, MCSweeney CS. Development of a real-time PCR assay for monitoring anaerobic fungal and cellulolytic bacterial populations within the rumen. FEMS Microbiol Ecol. 2006;58:572-82.

23. Ilić DP, Nikolić VD, Nikolić LB, Stanković MZ, Stanojević LP, Cakić MD. Allicin and related compounds: biosynthesis, synthesis and pharmacological activity. Facta Univ. 2011;9:9-20. 
24. Kamruzzaman M, Liang X, Sekiguchi N, Sano H. Effect of feeding garlic leaf on microbial nitrogen supply, kinetics of plasma phenylalanine, tyrosine and protein synthesis in sheep. Anim Sci J. 2014;85:542-8.

25. Vaithiyanathan $S$, Bhatta R, Mishra AS, Prasad R, Verma DL, Singh NP. Effect of feeding graded levels of Prosopis cineraria leaves on rumen ciliate protozoans, nitrogen balance and microbial protein supply in lambs and kids. Anim Feed Sci Technol. 2007;133:177-91.

26. Busquet M, Calsamiglia S, Ferret A, Carro MD, Kamel C. Effect of garlic oil and four of its compounds on rumen microbial fermentation. J Dairy Sci. 2005;88:4393-404.

27. Chaves AV, He ML, Yang WZ, Hristov AN, McAllister TA, Benchaar C. Effects of essential oils on proteolytic, deaminative and methanogenic activities of mixed ruminal bacteria. Can J Anim Sci. 2008;88:117-22.

28. Patra AK, Kamra DN, Bhar R, Kumar R, Agarwal N. Effect of Terminalia chebula and Allium sativum on in vivo methane emission by sheep. J Anim Physiol An N. 2011;95:187-91.

29. Zhu Z, Mao S, Zhu W. Effects of ruminal infusion of garlic oil on fermentation dynamics, fatty acid profile and abundance of bacteria involved in biohydrogenation in rumen of goats. Asian-Australas J Anim Sci. 2012;25:962-70

30. Newbold CJ, Lassalas B, Jouany JP. The importance of methanogens associated with ciliate protozoans in ruminal methane production in vitro. Lett Appl Microbiol. 1995;21:230-4.

31. Cardozo PW, Calsamiglia S, Ferret A, Kamel C. Screening for the effects of natural plant extracts at different $\mathrm{pH}$ on in vitro rumen microbial fermentation of a high-concentrate diet for beef cattle. J Anim Sci. 2005;83:2572-9.

32. Reuter HD, Koch HP, Lawson LD. Therapeutic effects and applications of garlic and its preparations. In: Koch HP, Lawson LD, editors. Garlic: the science and therapeutic application of Allium sativum L. And related species. Baltimore: Williams and Wilkins; 1996. p. 135-213.

33. Kongmun P, Wanapat M, Pakdee P, Navanukraw C. Effect of coconut oil and garlic powder on in vitro fermentation using gas production technique. Livest Sci. 2010:127:38-44.

34. Anassori E, Dalir-Naghadeh B, Pirmohammadi R, Taghizadeh A, Asri-Rezaei S, Maham M, et al. Garlic: a potential alternative for monensin as a rumen modifier. Livest Sci. 2011;142:276-87.

35. Patra AK, Yu Z. Effects of essential oils on methane production and fermentation by, and abundance and diversity of, rumen microbial populations. Appl Environ Microb. 2012;78:4271-80.

36. Takenaka A, Itabashi H. Changes in the population of some functional groups of rumen bacteria including methanogenic bacteria by changing the rumen ciliates in calves. J Gen Appl Microbiol. 1995;41:377-87.

37. Rees LP, Minney SF, Plummer NT, Slater JH, Skyrme DA. A quantitative assessment of the antimicrobial activity of garlic (Allium sativum). World J Microbiol Biotechnol. 1993;9:303-7.

\section{Submit your next manuscript to BioMed Central and we will help you at every step:}

- We accept pre-submission inquiries

- Our selector tool helps you to find the most relevant journal

- We provide round the clock customer support

- Convenient online submission

- Thorough peer review

- Inclusion in PubMed and all major indexing services

- Maximum visibility for your research

Submit your manuscript at www.biomedcentral.com/submit

CBiomed Central 